\title{
Conductance interaction identification by means of Boltzmann distribution and mutual information analysis in conductance-based neuron models
}

\author{
Roberto Santana ${ }^{1 *}$, Concha Bielza², Pedro Larrañaga ${ }^{2}$ \\ From Twenty First Annual Computational Neuroscience Meeting: CNS*2012 \\ Decatur, GA, USA. 21-26 July 2012
}

Recent research has focused on the causal paths that explain how neuron ionic-conductances interact to produce a particular electrophysiological behavior. Pharmacological blockage methods, neuromodulators and genetic knockouts are among the techniques used to study this issue. In this paper we propose a probabilistic approach based on the computation of the Boltzmann distribution and the mutual information of conductance interactions to learn higher-order, not necessarily pair-wise, potential coregulation mechanisms from a database of the crustacean stomatogastric ganglion pyloric circuit models. The original database was built from experimental data obtained from lobster stomatogastric neurons [2,3]. The eight currents in the single-compartment model are based on the lobster stomatogastric ganglion neurons currents.

The basic idea of our work is to assign a probability value $p(x)$ to each neuron model depending on whether or not it satisfies a given electrophysiological property. To assign these values we use the Boltzmann probability distribution, commonly used in statistical physics to associate a probability with a system state according to its energy [4]. From the Boltzmann distribution we compute the mutual information to measure the strength of interaction between a pair of conductances at the time of producing a particular electrical activity.

The particular characteristics of silent neurons were captured in the uneven distribution of bivariate marginal probabilities computed from the Boltzmann distribution. Among all conductance pairs, the highest bivariate probabilities are reached for conductance pairs $\left(\mathrm{g}_{\mathrm{KCa}}, \mathrm{g}_{\mathrm{Kd}}\right),\left(\mathrm{g}_{\mathrm{Na}}\right.$, $\left.\mathrm{g}_{\mathrm{KCa}}\right)$ and $\left(\mathrm{g}_{\mathrm{CaT}}, \mathrm{g}_{\mathrm{CaS}}\right)$. With respect to previous analysis of

\footnotetext{
* Correspondence: roberto.santana@ehu.es

'Department of Computer Science and Artificial Intelligence, University of the Basque Country, Spain

Full list of author information is available at the end of the article
}

the group of silent neurons, the correlation $\left(\mathrm{g}_{\mathrm{CaT}}, \mathrm{g}_{\mathrm{CaS}}\right)$ was the only significant linear correlation identified for silent models in [1]. There were another three conductance relationships reported in [1] that fitted statistical criteria for correlations, but did not appear to have a linear relationship. They were $\left(\mathrm{g}_{\mathrm{H}}, \mathrm{g}_{\text {leak }}\right),\left(\mathrm{g}_{\mathrm{KCa}}, \mathrm{g}_{\mathrm{Kd}}\right)$ and $\left(\mathrm{g}_{\mathrm{KCa}}, \mathrm{g}_{\mathrm{CaT}}\right)$. All these correlations were identified as significant correlations of the computed Boltzmann distribution

Our results show that probabilistic modeling based on the Boltzmann distribution can capture potential co-regulations that are not captured by the correlation analysis. The extension to capture higher-order dependencies between conductances is also straightforward. Furthermore, our results indicate that mutual information analysis allows a more detailed visualization of the structure of the conductance landscape for conductance-based neuron models.

\section{Acknowledgements}

This work has been partially supported by the Saiotek and Research Groups 2007-2012 (IT-242-07) programs (Basque Government), TIN2010-14931, TIN2010-20900-C04-04, Consolider Ingenio 2010 - CSD2007-00018 projects and the Cajal Blue Brain project (Spanish Ministry of Science and Innovation)

\section{Author details \\ ${ }^{1}$ Department of Computer Science and Artificial Intelligence, University of the Basque Country, Spain. ${ }^{2}$ Departamento de Inteligencia Artificial, Universidad Politécnica de Madrid, Spain.}

Published: 16 July 2012

\section{References}

1. Hudson AE, Prinz AA: Conductance ratios and cellular identity. PLoS Comp Biol 2010, 6:e1000838.

2. Prinz AA, Billimoria CP, Marder E: Alternative to hand-tuning conductancebased models: Construction and analysis of databases of model neurons. J. Neurophys 2003, 90:3998-4015. 
3. Turrigiano $G G$, LeMason $G$, Marder E: Selective regulation of current densities underlies spontaneous changes in the activity of cultured neurons. J Neurosci 1995, 15:1129-1131.

4. van Kappen N: The Stochastic Processes in Physics and Chemistry. North Holland; 1992.

doi:10.1186/1471-2202-13-S1-P100

Cite this article as: Santana et al:: Conductance interaction identification by means of Boltzmann distribution and mutual information analysis in conductance-based neuron models. BMC Neuroscience 2012 13(Suppl 1): P100.

Submit your next manuscript to BioMed Central and take full advantage of:

- Convenient online submission

- Thorough peer review

- No space constraints or color figure charges

- Immediate publication on acceptance

- Inclusion in PubMed, CAS, Scopus and Google Scholar

- Research which is freely available for redistribution 